\title{
The Role of the City Transport in Prilep and Its Application in the Tourism in the Republic of Macedonia*
}

\author{
Cane Koteski \\ Goce Delcev University, Stip, Republic of Macedonia
}

\begin{abstract}
Public transport in Prilep has been in existence since 2014. In this scientific paper, the author wants to present the problem of the research, as well as the goal that this research wants to achieve, which is improvement of the city transport in the city of Prilep, which is located in the Republic of Macedonia, and it is in the fourth place according to the number of inhabitants in the country. For this scientific work, 200 users of public transport have been surveyed, which should enable availability, timeliness, realization, and success in the offered service, and provide solutions for the public city transport in Prilep, Republic of Macedonia. They are proposed by the citizens who live in the distant settlements and the periphery from the central city part, additional two new lines connecting the peripheral parts of the city with the city center of Prilep, for which the local government and the public transport company voted positively. Their inclusion in permanent lines will ensure good public transport. Public urban transport will contribute to sustainability and its application in tourism for panoramic sightseeing of the city.
\end{abstract}

Keywords: public transport, lines, application, services, tourism

\section{Introduction}

This paper aims to emphasize the public urban transport as a pillar in the urban areas as against the weight of the dominant cars, which with great care entered the policies of the local mayors from the end of the 20th and the beginning of the 21st century, both in our country and in other cities of our planet (Porta \& Scheurer, 2006). Changes in public urban transport and its improvement and implementation somewhere give positive results, and in spite of the great efforts made, it is still difficult to make public transport more interesting for the population. Public transport is new and very young and has just started to be used since 2014. However, public transport in a short time became an important part of the sustainable transportation system of the city of Prilep. The interest in the public city transport depends primarily on the quality of the services offered on the whole territory of the city of Prilep. The current situation of the public city transport in Prilep is very bad, because from the very beginning of its work, there were positive factors. The offered services of the citizens and their average quality, the initial variation in the number of users of the public transport, the use of vehicle relativity since the beginning of the public enterprise, the financial support, the

\footnotetext{
* Acknowledgements: This scientific paper was published as part of the research project "Possibilities and Perspectives for the Development of Tourism in the Black River Basin” funded by Goce Delcev University, Stip, Macedonia (Contract No. 0206-151/16, 0201-545/9 and 0307-98/77 from 01.11.2017).

Cane Koteski, Associate Professor, Faculty of Tourism and Business Logistics, Goce Delcev University. Email: cane.koteski@ugd.edu.mk.
} 
low availability of new investments, and the improvement of the services are parts of the existing problems (Atanasova \& Angelevska, 2011). This situation imposes the need for temporary and organized resolution of the problems in the public city transport in the city of Prilep. In this scientific research paper, the chapters on the occurrence of public urban traffic in the city of Prilep and the number of passengers transported in the period of 2014-2017 were analyzed: a field survey of 200 users of public urban traffic from four groups, students of primary and secondary education, students and occupied citizens at bus stops, number of employees in the public enterprise, financial operation of the public enterprise, a survey of the surveyed participants in public urban traffic by gender and age structures, elements defining Nira quality of service, quality assessment services, the aim of the trip, frequency of the use of public transport, the total number of trips per day per family, and the most widely used transport in the town of Prilep. The needs of the citizens for a comfortable, safe, reliable and environmentally clean public transport in Prilep can be solved with quality public transport, which should provide high capacity for transportation and a competitive price on the market for consumers. The purpose of all the aforementioned and proposed measures is directed towards the support of the public urban transport that can have the greatest potential for resolving the problems of the public city transport. Of course, we should not forget that public transport in the city is the most important part towards the goal of achieving the ecological, social, and economic results. By promoting the public urban transport, we will contribute to the initiative for mobility and success, which will force the citizens to be the second choice for use in the city transport.

By doing so, we will raise public transport as an important component in the development policy of public transport as an important and sustainable urban transport, which will help with the new types of electric buses in improving the city life and lesser destruction of the environment in the city of Prilep and in the much larger cities in the country and other countries, whose number accounts for several million inhabitants.

\section{Occurrence of City Transport in Prilep}

Public city transport in Prilep for the first time appeared on April 16, 2014 and has already existed for four years. This public enterprise was established by the Municipality of Prilep, also in the Municipality of Prilep since 2000. There are two private public transport companies: Runamak and Jandragoma. The company Runamak addresses the municipal line Prilep-Topolcani-Kanatlarci and the company Jandragoma addresses the line Prilep-Topolcani-Chepigovo.

\section{Passengers Transported in the Period of 2014-2017}

The public enterprise for Public City Transport "Parkinsi Street Prilep" started its work on April 16, 2014. In the period of 2014-2017, a total of 1,066,021 passengers were transported (see Table 1). The results were obtained on the basis of payment with coins on buses and electronic cards that they paid in the collection center. These results are not taken into account annually for 1,000 students from the secondary schools and 1,000 employees in institutions where the payment is with an invoice and which use the city transport services-Prilep. This means that the number of passengers transported per month will increase by 166 . 
Table 1

A Review of the Public Transport of Passengers With City Buses in the Period of 2014-2017

\begin{tabular}{lrrrr}
\hline \multirow{2}{*}{ Months } & \multicolumn{4}{c}{ Years } \\
\cline { 2 - 5 } & 2014 & 2015 & 2016 & 2017 \\
\hline January & $/$ & 25,561 & 23,403 & 18,851 \\
February & $/$ & 25,094 & 25,433 & 20,882 \\
March & $/$ & 25,322 & 28,533 & 25,221 \\
April & 5,821 & 26,534 & 27,439 & 25,618 \\
May & 26,761 & 25,444 & 25,839 & 25,443 \\
June & 28,507 & 25,318 & 27,242 & 26,279 \\
July & 21,266 & 18,252 & 15,799 & 15,647 \\
August & 16,591 & 17,500 & 19,478 & 18,350 \\
September & 20,495 & 22,654 & 25,961 & 23,101 \\
October & 24,407 & 25,136 & 26,317 & 2,950 \\
November & 26,167 & 28,471 & 28,492 & 29,947 \\
December & 25,581 & 28,402 & 28,048 & 274,752 \\
Total & 195,596 & 293,688 & 301,985 & \\
\hline
\end{tabular}

Note. Source: Public enterprise PUP. Prilep 01.12.2017, 02.01.2018.

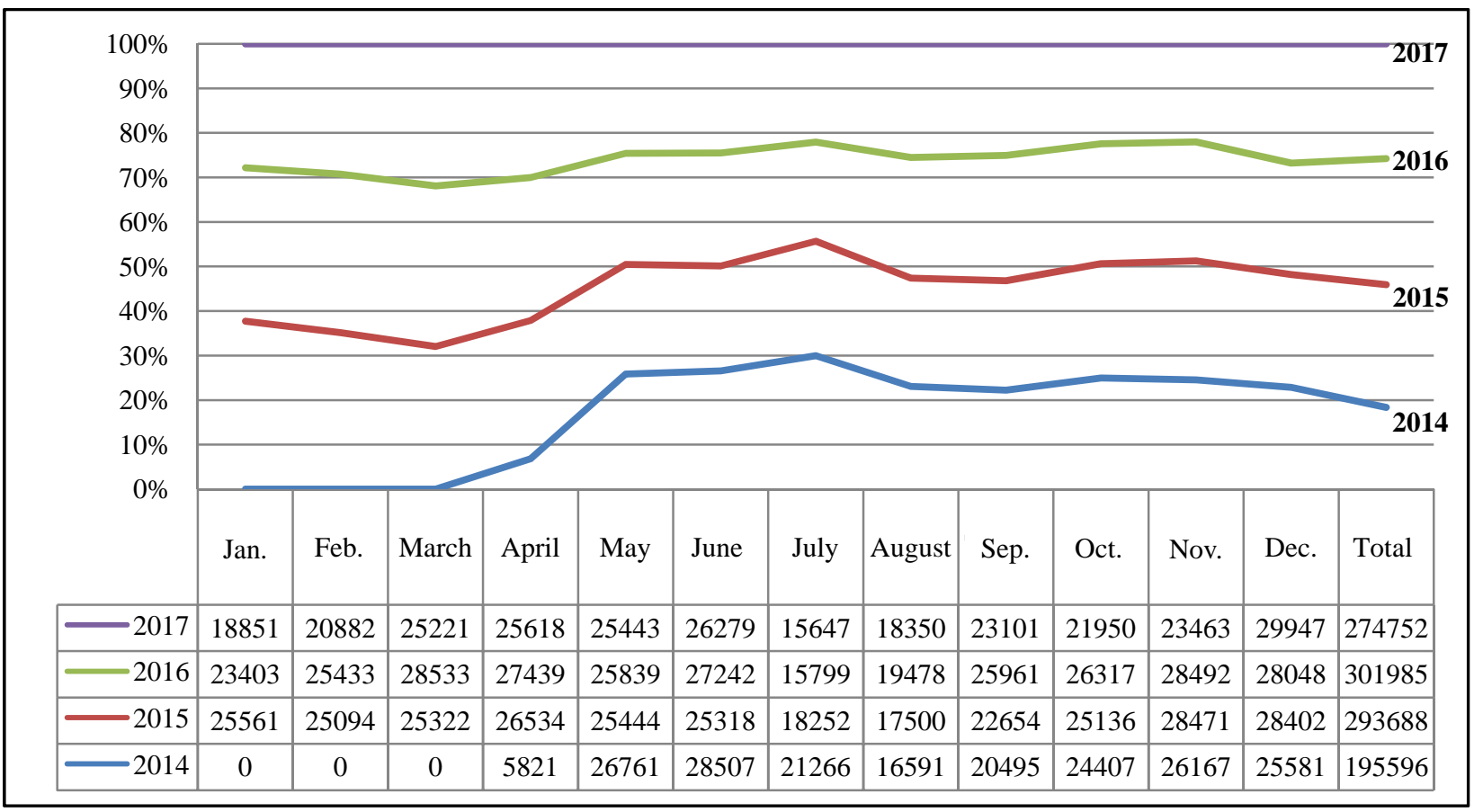

Figure 1. Overview of the public transport of passengers with city buses in the period of 2014-2017.

In Figure 1, the public transport of passengers is presented for months and years. According to the data, we find that the largest number of passengers was transported in 2016 (301,985) followed by 293,688 passengers in 2015.

\section{Employed Workers}

The public utility company, Prilep, employs 34 workers, of whom 20 are drivers, five are in administration, four are in bookkeeping, three are in the collection center, and two are hygienists (see Figure 2). 


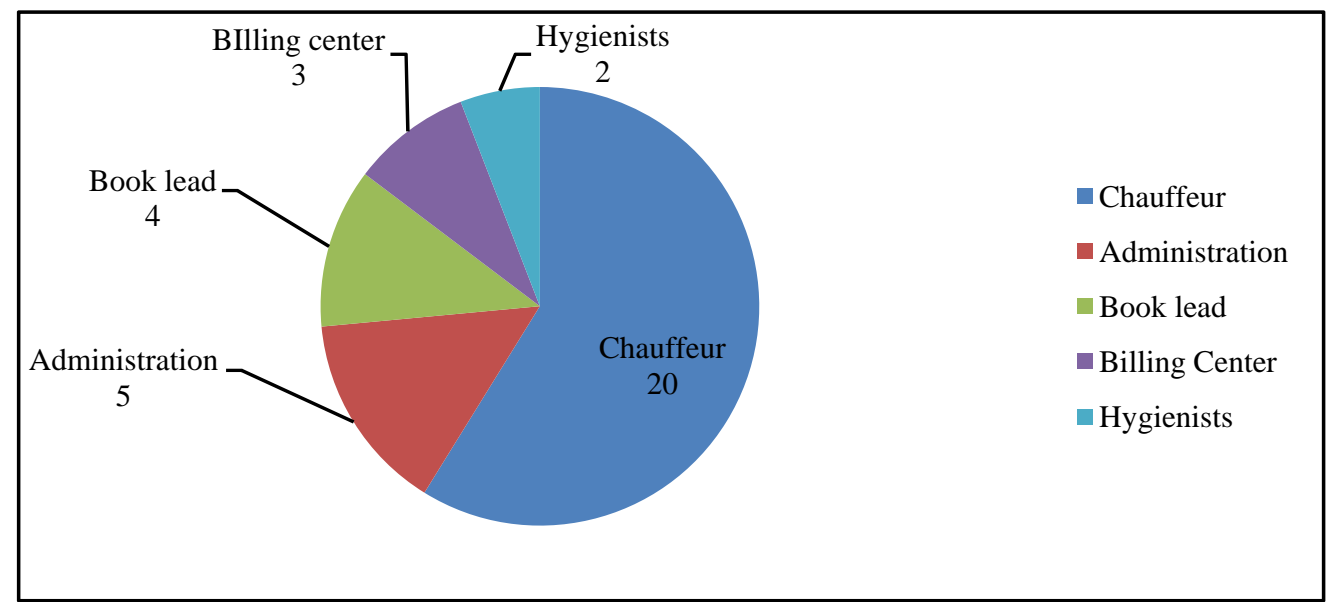

Figure 2. Number of employees in the public enterprise.

Employees regularly receive salaries every month. The average wage of a driver in the public enterprise is MKD17,500 or $€ 283.17$, bookkeepers monthly earn from MKD23,000 to MKD28,000 or from $€ 372.16$ to $€ 453.07$, the employees in the monthly payment center earn MKD13,000 or €210.35, the hygienists per month earn MKD12,000 or €194.17.

\section{Gender and Age Structure of 200 Surveyed Users of Public City Transport in the City of Prilep in the Republic of Macedonia}

According to the data from the surveyed 200 public transport users in the city of Prilep (see Figure 3), the following results were obtained: With respect to gender and age, the surveyed passengers are divided into eight groups: The first group is composed of people aged 11-15, where the female gender is dominant, the second group is at the age of 16-25, and the third group is the age group of 36-45 years old, with the female gender prevailing, followed by groups of people who aged 0-10 and 26-35 years old, where the female gender prevails; the next group consists of people aged 56-64 years old, where the female sex prevails. As for age groups of 46-55 and over 64 years old, the male sex predominates. According to the results of the survey of 200 surveyed passengers, we find that female passengers prevail in five of the eight age groups; one is equalized and only in two age groups more passengers are from the male sex.

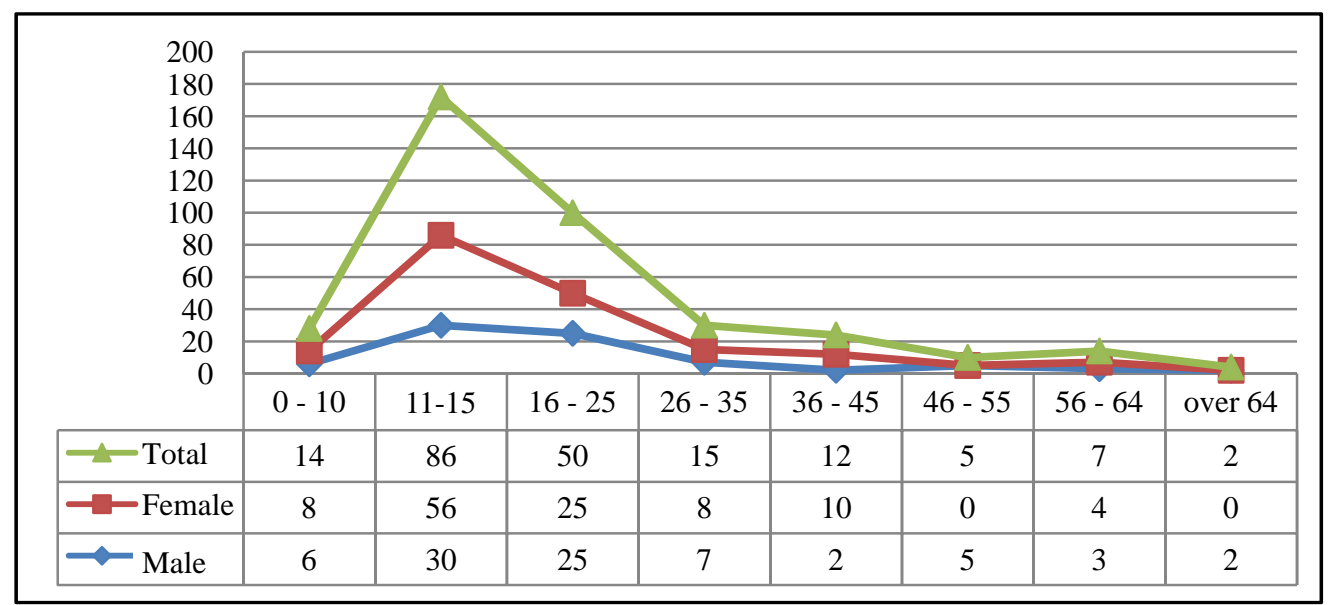

Figure 3. An overview of the gender and age structure of 200 surveyed users of public transport in Prilep. 


\section{Public City Transport in Prilep: Analysis of the Existing Situation}

The public city transport in Prilep is carried out by the Public Enterprise-Prilep (PUP), while in the suburban traffic from the city to the village settlements and vice versa more licensed operators participate. The traffic services in the urban city of Prilep are realized with three urban regular lines: Lines 1, 2, and 3, one extraordinary (weekly) line plus two new lines (Lines 4 and 5), which in the course of 2018 should be introduced in the public city transport in Prilep.

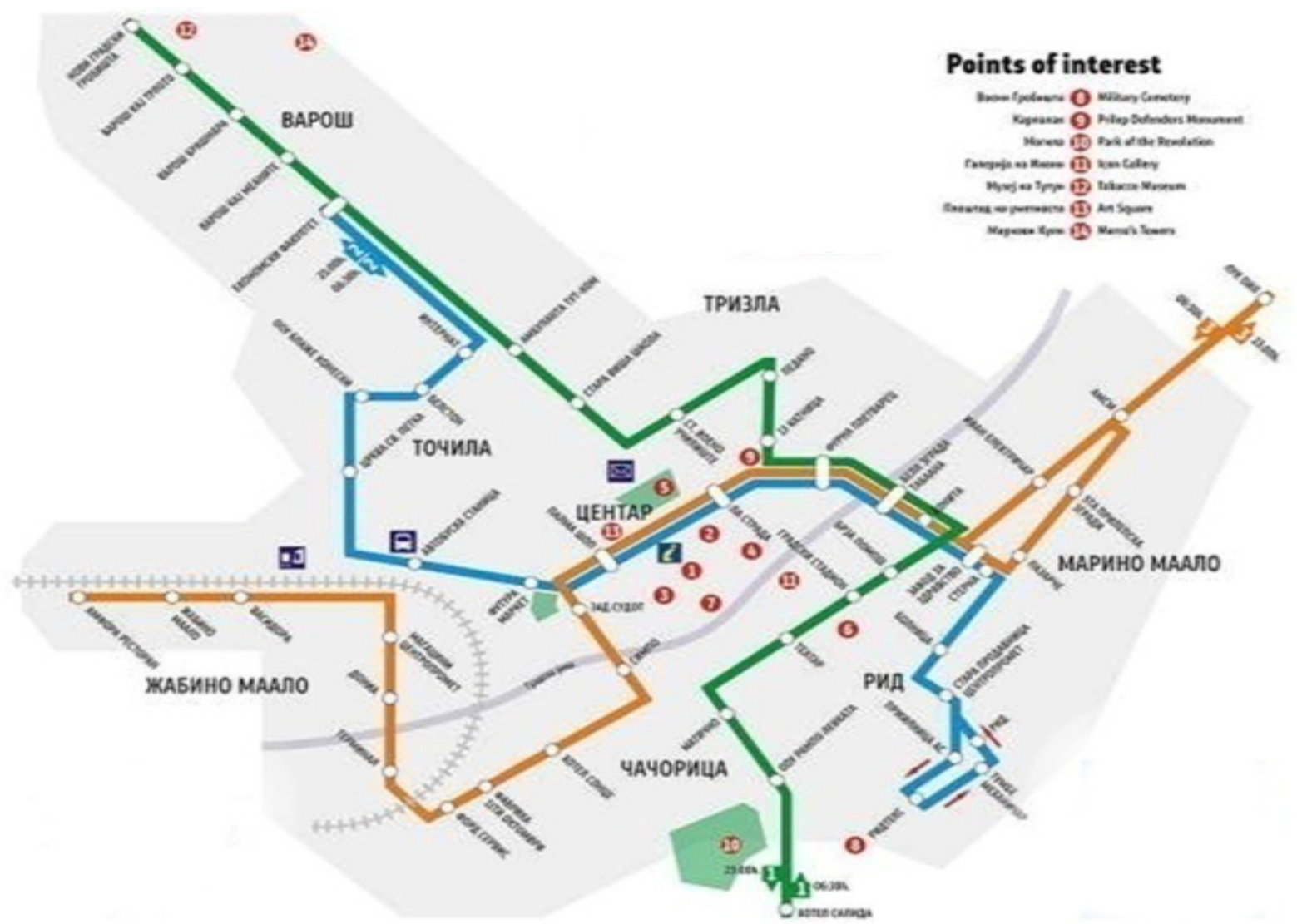

Figure 4. Current lines in the public city transport in Prilep.

As can be seen from Figure 4, the public urban transport in Prilep is performed only along circular lines. As a reason, the current situation is characterized by an unstable public transport service. By using only circular lines, frequent services are only in one part of the city, or in this case only the central city area is planned.

In Figure 5, an extraordinary (weekly) line is added, which complements the public city transport when there are more passengers on Sunday, when most of the visitors are part of the Prilep residents visiting the new cemeteries that are located outside the city at $4 \mathrm{~km}$. This line starts from Hotel Salida - PS Rampo Lefkata stem - theater - stadium - hospital - health institution - Bonita - oven plow -13th floor - Pedano - Mice Kozar sturgeon - health center - grain hall Prilep - veterinary station - bus station - Tocila Tediko - PS Blaze Koneski Belston - boarding school - Faculty of Economics - Varosh near the means - Varos at the barracks - Varos near the dungeon - new city cemetery. 


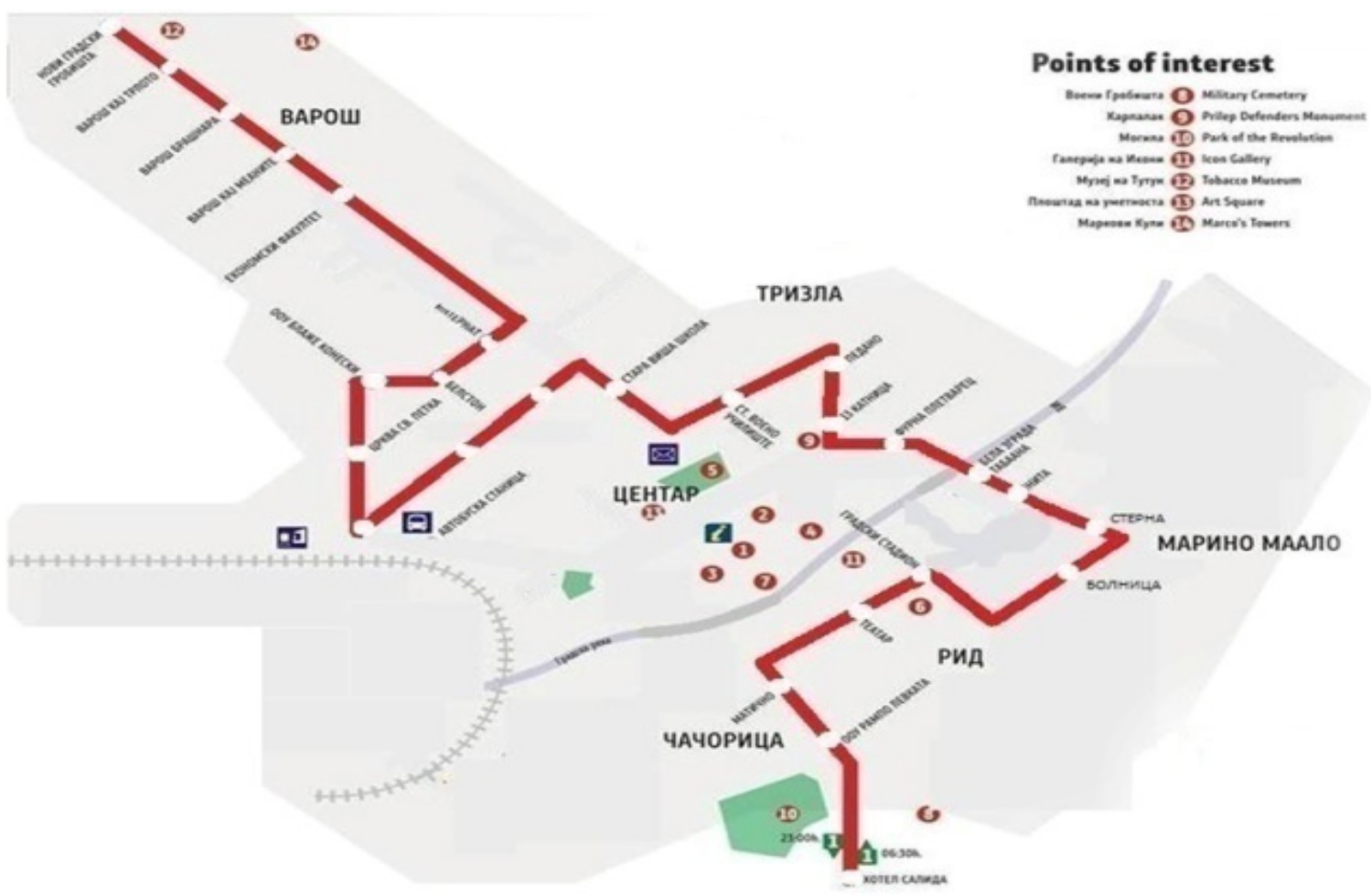

Figure 5. Extraordinary (weekly) line.

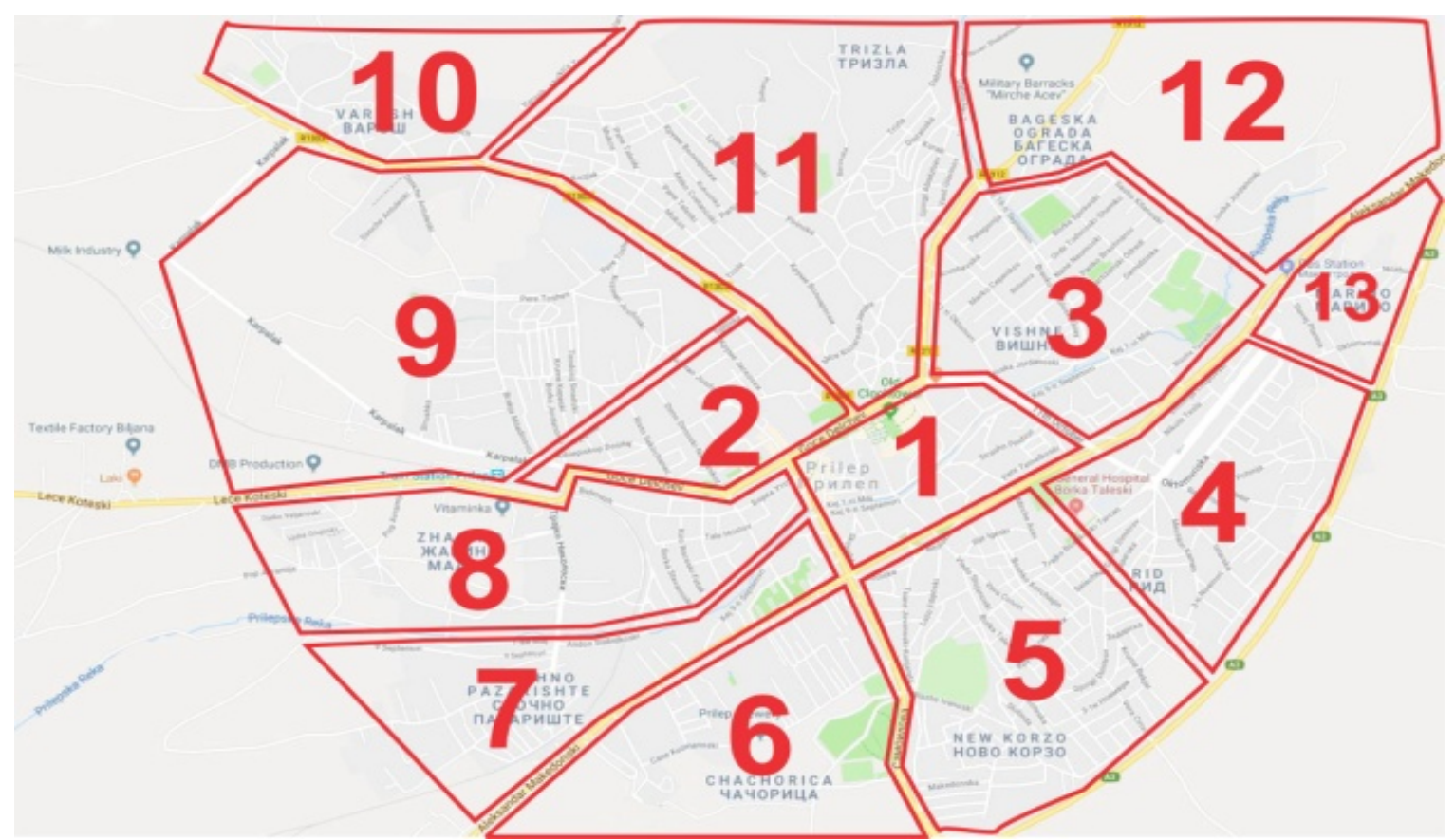

Figure 6. Traffic zones in the city of Prilep (total of 13 zones).

If we make an additional analysis of zone map (see Figure 6), we will notice that suburban areas have minimal or insufficient service, providing only one line, for example, the suburban (Zones 4, 5, 6, 7, 8, 9, 10, 11, 12, and 13), while the central part of the city has a permanent urban transport such as Zones 1, 2, and 3. 
In the road network in the city of Prilep, public transport and vehicles use the same traffic lanes along with other types of vehicles, with respect to the traffic signal system that is unique to the entire public city transport. In Prilep, there are no separate lanes for bus public transport in the existing traffic network. In Prilep, so far public transport vehicles have never had an advantage at crossroads. From the analysis of the current state of public transport, we point out certain deficiencies and anomalies related to the efficiency and attractiveness of the quality service, such as low level of trust in public transport services, low frequency, and low comfort (Atanasova \& Angelevska, 2011):

(1) Vehicles used in public urban traffic are of average age of 1998, all (20), and have weaker technical characteristics of buses;

(2) Passengers do not travel long in time, stops every 250-300 m;

(3) Bus stops are with poor infrastructure;

(4) There are no maps for public transport relations; there is no coordination with other local and inter-city lines; there is a lack of a single tariff system.

All these problems in public transport in Prilep indicate the need for changes in the current situation. The goal of the changes must be towards the improvement of public transport services in Prilep by introducing two new lines (Lines 4 and 5).

\section{Problems in the City Transport and Their Categorization}

Of all these mentioned problems in the public urban transport in Prilep, we can categorize them into four categories. They arise from the reason that technical efficiency cannot be analyzed independently of existing institutions or regulatory constraints (Roy \& Billon, 2007). For the correct and precise identification of the problems, the next element for solving them is given and analyzed.

\section{Problems of Organizational Character}

Over the last 15 years, several European countries have made important changes in the organization of their regulatory frameworks for their local public transport systems. Reforms are promoted by the European Commission in 2005, aimed at preventing the decline of the sector, increasing economic efficiency, and improving the quality of services. The basis of these policies is the hypothesis that organizational and regulatory settings affect performance in work (Roy \& Billon, 2007).

Organizational problems in public urban transport relate to the way the service market is defined. In Prilep, public urban transport is performed by the public enterprise for this purpose and taxi companies. The public service provider tended to provide a service not only in the central part of the city, where the number of users is the largest, by introducing new lines and providing a successful service to the citizens in the peripheral part of the city. Public urban passenger transport in Prilep fulfills its role and functions as a unique system with unique and coordinated routes and unique tariff system (Krstanoski, 2003). While this requirement is met, whether in the future, operators will be more, socially or privately owned. Very important is the creation of future policies for public urban transport and its development (Krstanoski, 2017).

\section{Financial Operations of the Company}

In the period of 2014-2017, a total of MKD 78,960,000 was realized, from which the data for the years that are realized in MKD are given in Figure 7. 


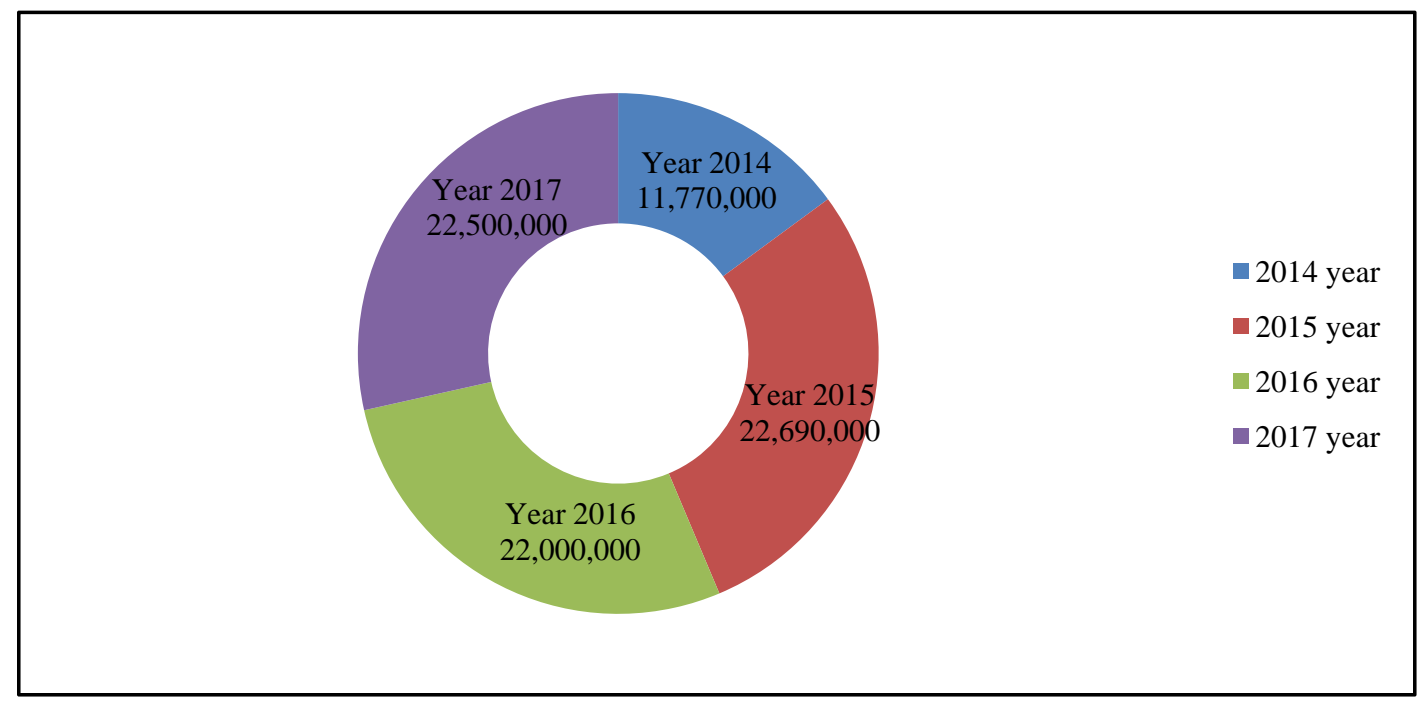

Figure 7. Financial operation of the public enterprise for urban transport in the period of 2014-2017.

In 2014, MKD 11,770,000 or €190,453 was realized, in 2015, realized MKD 22,690,000 or €367,152, in 2016, realized MKD 22,000,000 or €355,987, and in 2017, realized MKD 22,500,000 or €364,077, or in total for the whole period of 2014-2017 realized MKD 78,960,000 or $€ 1,277,669$. In Prilep, there is a real need to ensure the maximum quality of service and actual transport costs; on the other hand, there is a need for subsidizing public transport (Krstanoski, 2003).

The subsidies will cover the difference between the real price of public transport and the average ticket price (Koteski, 2017a; 2017b).

\section{Table 2}

Price List in Macedonian Denars and Euro

\begin{tabular}{ll}
\hline Ticket price for city lines & \\
\hline One ride & 20 denars, $€ 0.32$ \\
Seven rides & 120 denars, $€ 1.94$ \\
15 rides & 250 denars, €4.04 \\
50 rides & 600 denars, €9.70 \\
Student card for 50 students & 350 denars, €5.66 \\
Price of the card, unlimited time of use of the ride, supplemented in an electronic card & 80 denars, €1.29 \\
Free transportation of invalids from all categories & 0 \\
\hline
\end{tabular}
Note. Source: PUP.

\section{Service Quality Problems}

In the period from 2014 to 2017, the public enterprise for urban transport slowly focused on the quality of services and customer satisfaction (Eboli \& Mazzulla, 2007).

By improving the quality of service delivery, more users can be attracted. This can solve many problems, such as helping to reduce traffic congestion, air pollution and noise, as well as the consumption of various fuels, e.g., energy, because private individual transport will be less used. The quality of services is such a concept that is difficult to define and often interferes with pleasure (Sumaedi, Bakti, \& Yarmen, 2012). Maintaining the quality of service should be the basis for competitiveness in public transport (Krstanoski \& Atanasova, 2008). 
Measuring the quality of services is needed for the proper organization and operation of public urban transport. The results of the survey show that users will benefit from improved service, reliability, and reduction of crowds (Tyrinopoulos \& Aifadopoulou, 2008). The quality of public transport services and public services consists of several elements, which have different results obtained in the survey of 200 passengers (see Figure 8). The data are from the field survey on the public city transport for the city of Prilep in the period of November-December 2017, by the Faculty of Tourism and Business Logistics—Gevgelija. As part of this survey, during November and December 2017, a survey was carried out in 10 bus stops, one primary school Kliment Ohridski, the Foreign Language School of the Thames, the medical secondary school Gjorce Petrov, and the campus of the Goce Delcev University in Prilep.

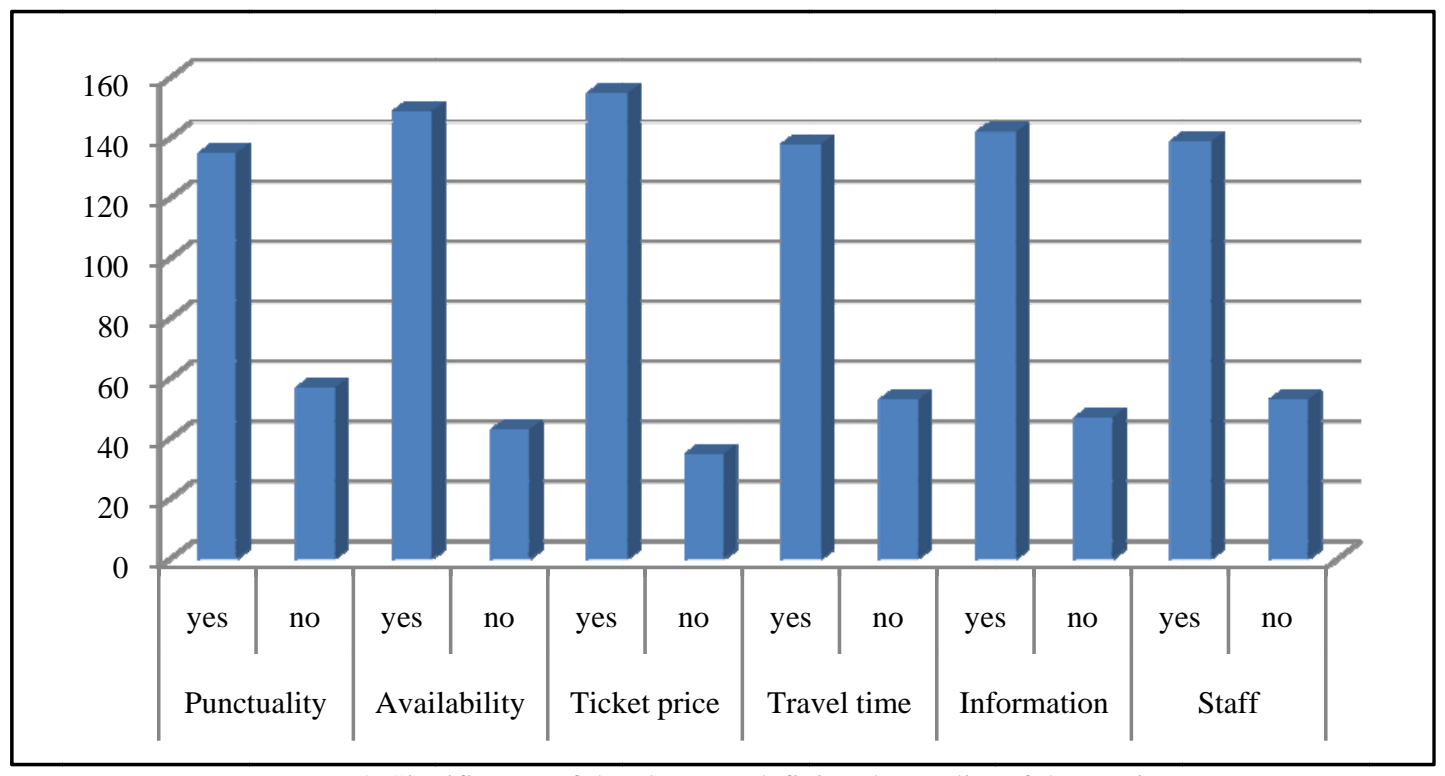

Figure 8. Significance of the elements defining the quality of the service.

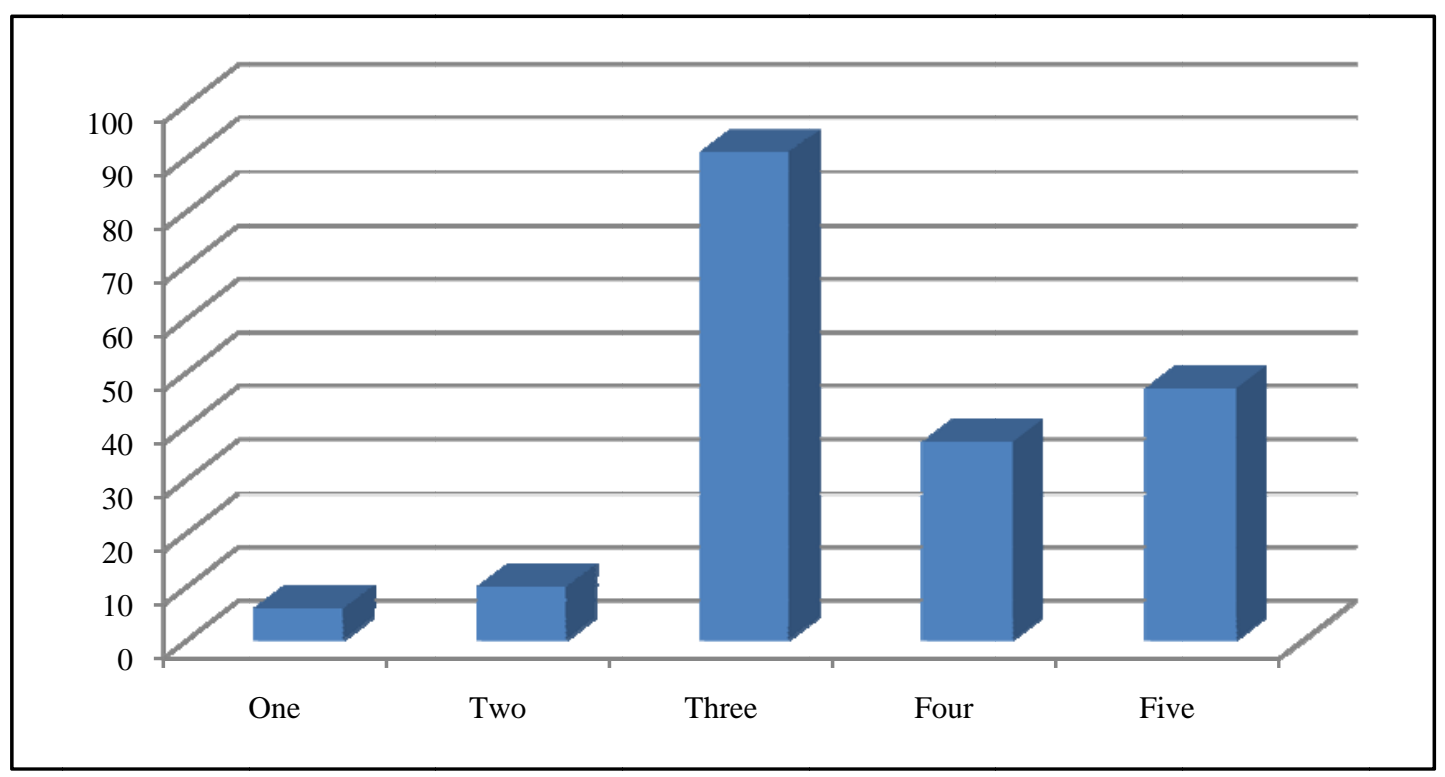

Figure 9. Total appraisal of the service quality (1 = Bad, 5 = Excellent). 
The worsening conditions for public transport in the city contributed to a lower level of service quality (45.5\% of users gave a score of 3, as shown in Figure 9). The carrier, the Public Utility Transport Company, has the best results obtained from the ticket price survey with $77.5 \%$ and availability with $74.5 \%$, while the accuracy of the service is $28.5 \%$, the travel time is $26.5 \%$, and the staff behavior is $26.5 \%$ at a very low level; the passengers are satisfied with the comfort of the old vehicles; the passengers are satisfied with the information; there is insufficient equipment at the bus stops and it is at a very low level. Only high-quality public transport can attract more passengers, thus contributing to the reduction of private urban travel cars. Today, many public transport companies apply quality control systems, together with scientific and technological assistance.

In the longer term, such initiatives can provide results in attracting more passengers and improving the economic performance of public enterprises and private companies (Tyrinopoulos \& Aifadopoulou, 2008).

\section{Problems With Transport Policy}

The integrated transport policy has a number of objectives, such as security, availability, sustainability, economic recovery, equity, finance, environmental protection, and others (TRL, 2004). In order to address these objectives for an integrated urban traffic policy, the city must first solve the problem of taxi transport. In Prilep and also in other cities in the country, there is a problem on the market in passenger transport by a large number of registered taxi drivers, from a single and possibly larger number of unregistered and illegal taxi drivers. That is the reason why this type of taxis represents unfair competition in public transport. The total number of registered taxis in Prilep was 250 in 2017. Public transport operators, although united in their association, did nothing to improve the poor state of public transport. In the coming period, based on the developed policy for sustainable public urban traffic, it should be a good idea to consider as a priority of public transport vehicles at signaled intersections. Priority measures should be introduced in the central traffic network, where traffic falls are frequent. In Prilep, there are several intersections in the central city area, which are crowded in the morning and afternoon.

\section{Guidelines for Shipping Development}

The previously explained categories for public transport problems can serve as a basis for defining a range of solutions. They will enable the development of public urban transport that is tailored to the needs and priorities of transport companies as a requirement (Tyrinopoulos \& Aifadopoulou, 2008):

(1) There are needs and priorities of transport companies;

(2) Analysis of the experience of similar European organizations;

(3) Exploring customer satisfaction/research dissatisfaction;

(4) Program for quality control of the transport company.

\section{Proposal for New Lines in City Transport}

The key factor in achieving the quality of services in public urban traffic and private motorized transport to the level of sustainable ways of transport is to reduce the participation of private vehicles in the central part of the city of Prilep at all costs (Krstanoski, 2003). 
The research and analysis of the current situation show the need for implementation of changes in the public city transport, in order to achieve accessible, timely, and efficient service for every inhabitant in Prilep. In Prilep, there are also zonal parking in the city center and two multi-storey garages. As a result, a reduction in the number of trips with private passenger cars is expected, but such a survey has not yet been done. If the problem with unregistered taxi drivers is solved in the upcoming period, these improvements should be followed by offered alternatives as a replacement for the car. In the first place is the public city transport with improved service, which will cover the whole area of the city of Prilep. In order to achieve competitive public transport, unlike widespread urban coverage and accessibility for a larger number of users, public urban transport has to be improved with its comfort and accuracy (Krstanoski, 2006). In many countries today, major investments have been made in the public transport system in order to make it more competitive with other public transport vehicles especially for private cars (Fellesson \& Friman, 2008). The satisfaction and comfort are increasingly placed in the foreground as a solution for the future development of public city bus transport (Krstanoski, 2017).

\section{Purpose of Travel and Frequency of Using Public Transport}

According to the obtained results from the survey conducted at the bus stops, primary, secondary schools and faculties related to the purpose of the trip and the frequency of use of the public city transport (see Figures 10 and 11). According to Figure 10, the highest percentages are for school/university and private work (75\% and 17\%). But if you add 1,000 employees who travel bus-by-bus to work every day, then the highest percentage of trips will have to be work at school/college.

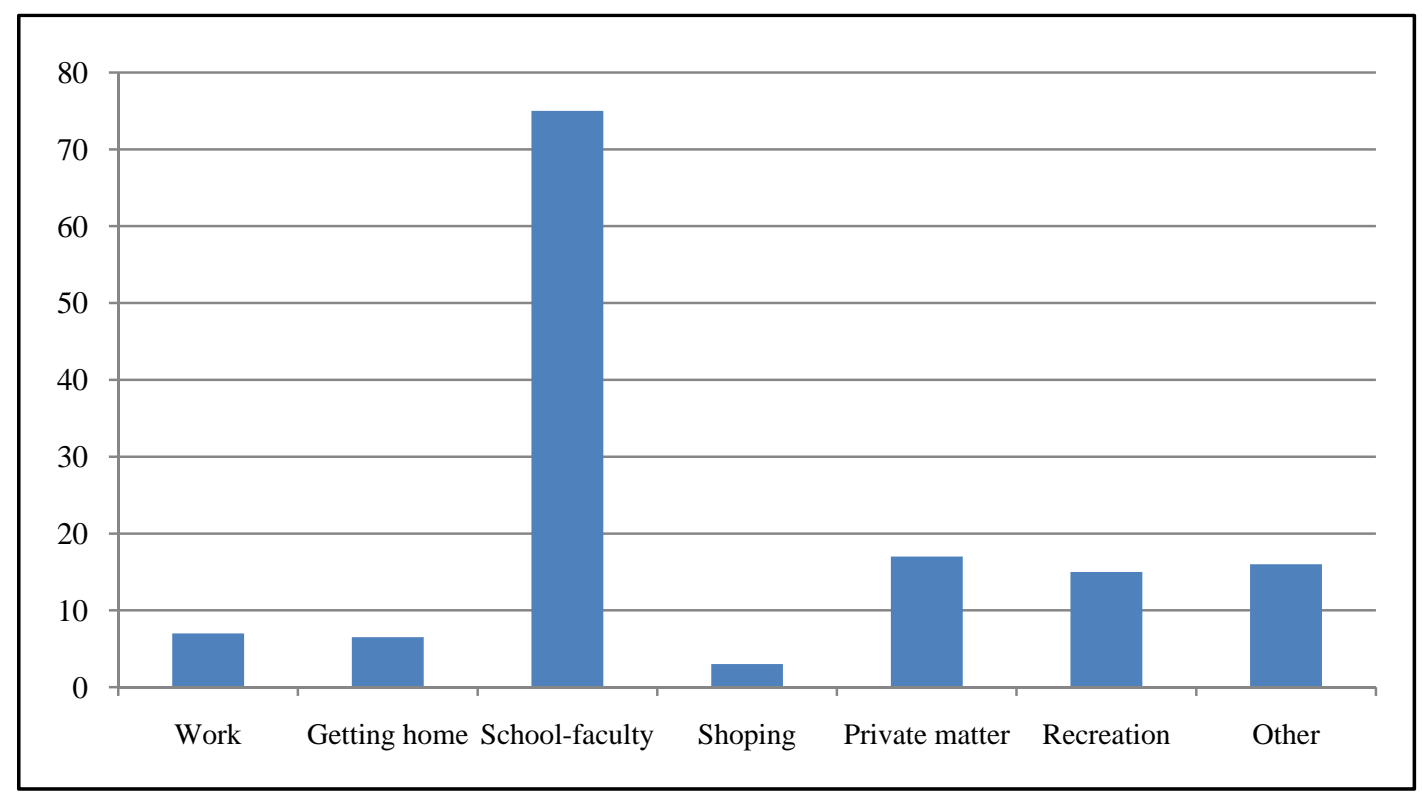

Figure 10. Purpose of the travel (\%).

Of the bus station surveyed passengers, the largest numbers are regular users every day (29.5\%), and a larger percentage (33\%) refers to periodic users (see Figure 11). 


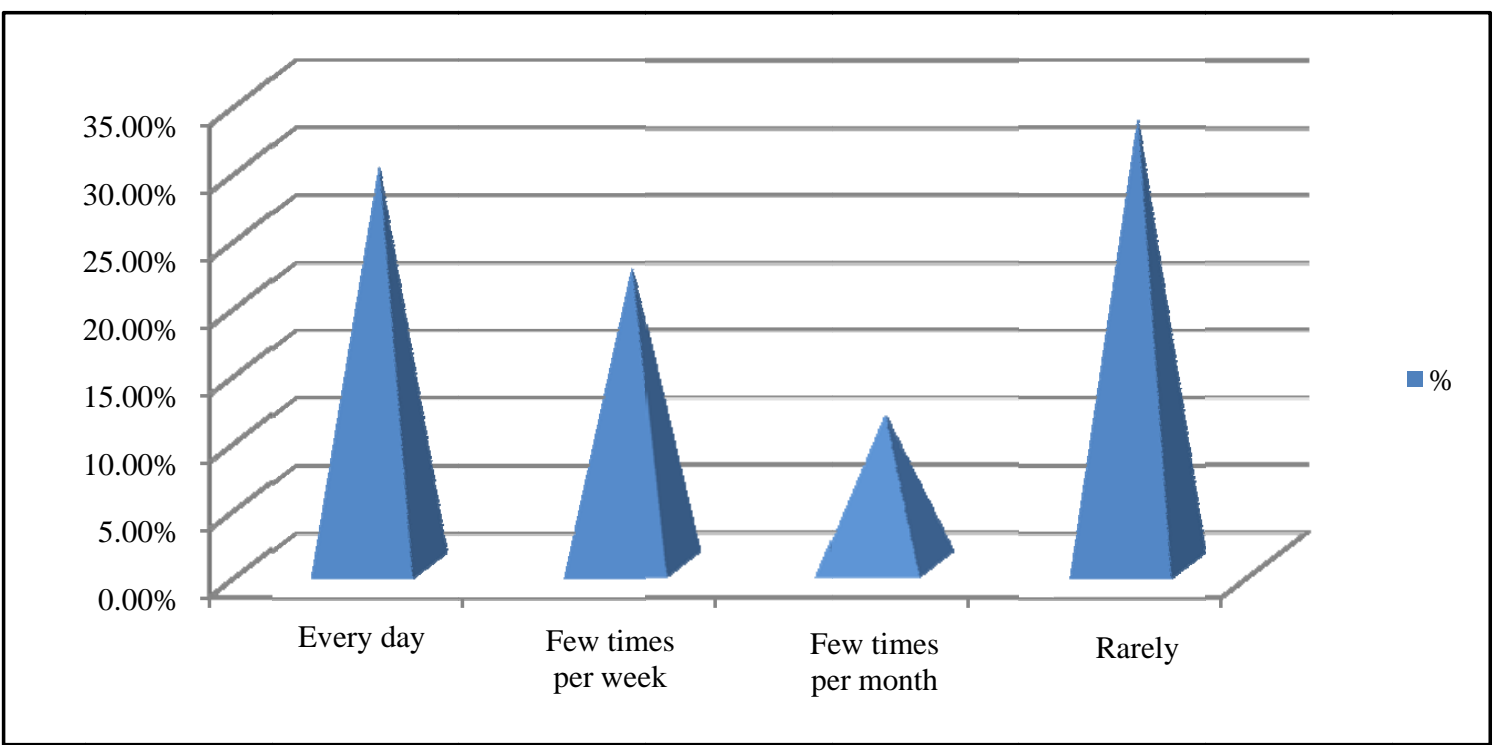

Figure 11. Frequency of usage of public transport in $\%$.

According to the obtained data from the survey, there is a need to promote and develop the existing services in the public city transport, supported by the percentage of the daily use of its services. The proposed new solutions for two new lines will contribute to improving the satisfaction of users of public urban transport. It is expected to be more functional. The existing traffic network of the city of Prilep supports these solutions; there is a need to supply optimum public services for city transport, covering the entire territory of the city. Changes in public city transport in Prilep should not be stopped only by the implementation of this proposal. Using the data from the public urban traffic survey, surveys have been carried out for the total number of trips daily per family (see Figure 12) and data on the most frequently used means of transport (see Figure 13).

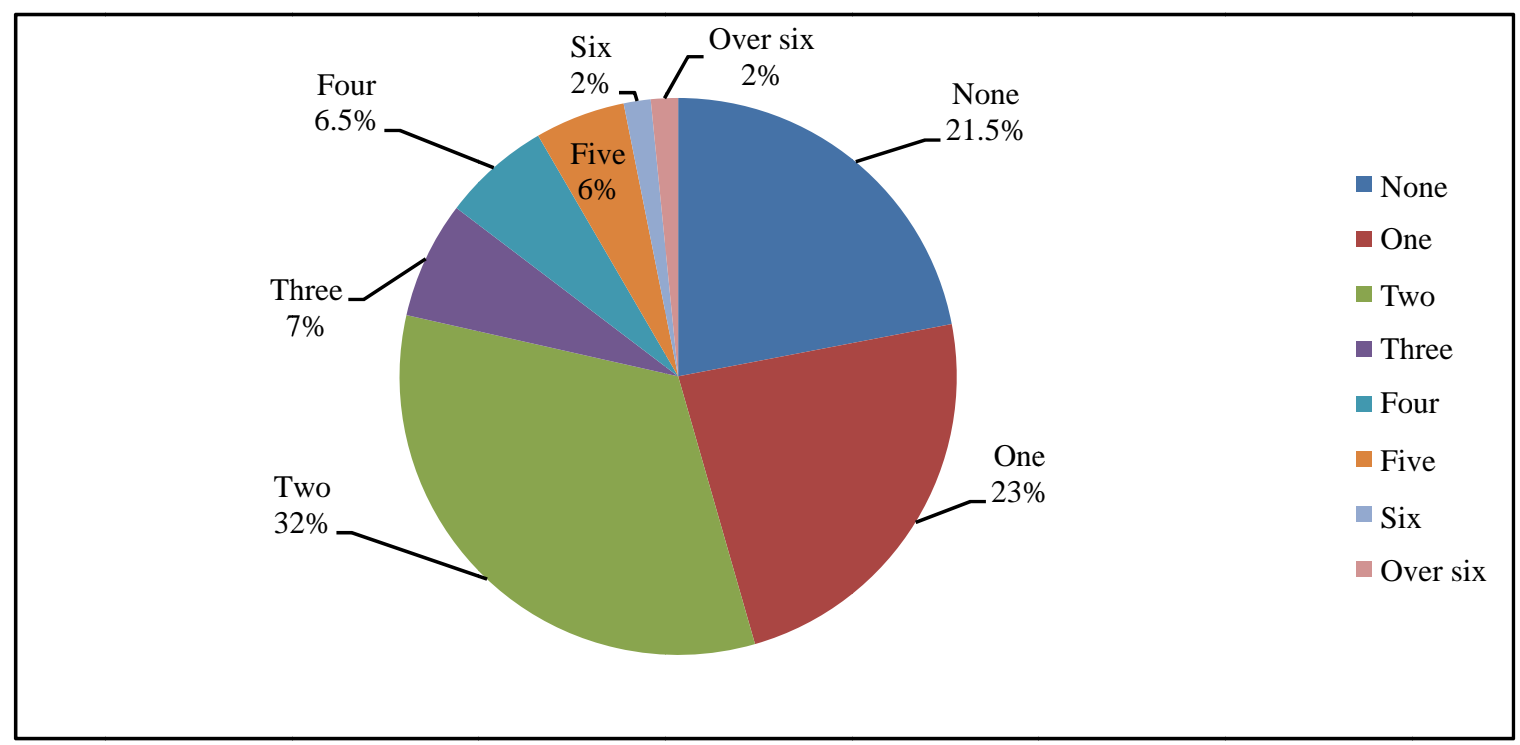

Figure 12. Total number of journeys daily per family in \%.

According to the data from Figure 12, it can be concluded that every family in the city of Prilep on a daily basis has numerous trips (one and two trips, or $23 \%$ and $32 \%$ ). 


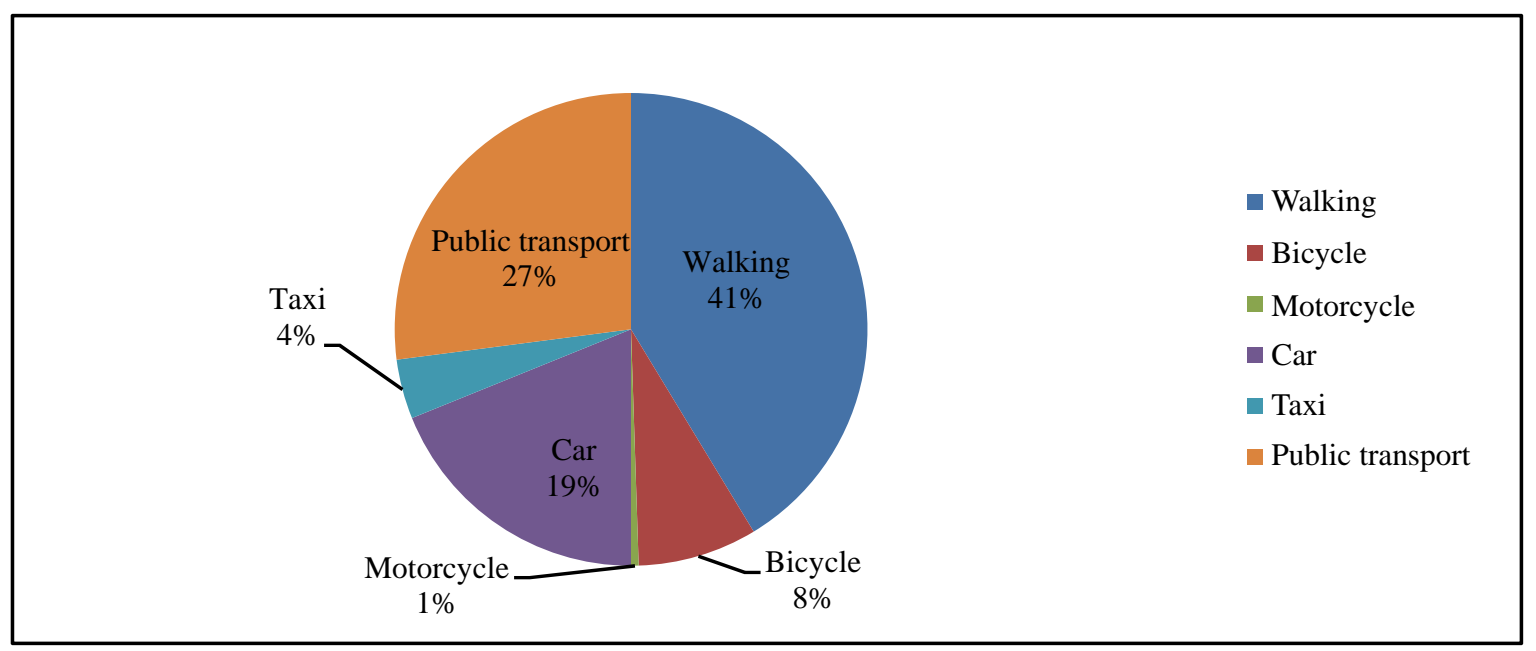

Figure 13. The most used means of transport in \%.

The most commonly used transport is walking on foot by $41 \%$, while the use of public transport is on the second place with $27 \%$ and in the third place is the private car with $19 \%$. According to these data, we can conclude that public transport is not the dominant mode of transport. This is a conclusion of the overall quality service assessment provided by the users themselves. All of these data are used in the process of designing new transport lines in the city of Prilep.

\section{Existing and New Lines for City Transport}

The establishment of the existing and new public transport lines should be in line with the demand for transport of users. The existing road infrastructure in Prilep can only be partially modified and upgraded as a result of the conditions imposed by the existing road infrastructure. It is proposed to introduce diametric lines. Their introduction shows that the public transport network will be transformed from a circular (ring) to a radial ring network.

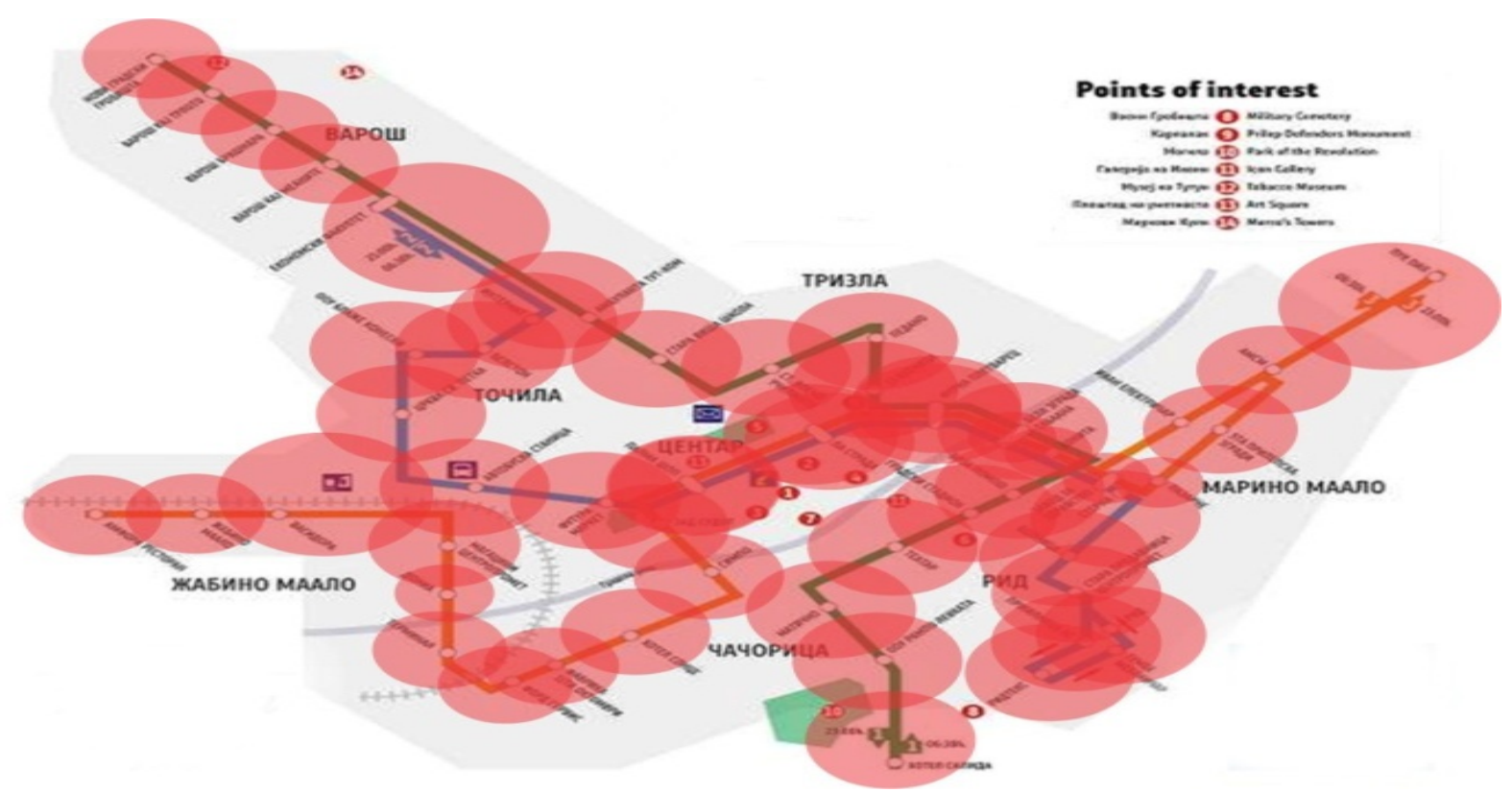

Figure 14. Radius of the constellation of bus stops. 
According to the map shown in Figure 14, bus stops are presented within a radius of 250-300 meters. This distance is the best choice for medium-sized cities, according to the number of inhabitants, which includes the city of Prilep with 69,704 inhabitants ( $<100,000$ inhabitants). According to the obtained data from the analysis, it helped us in the creation of the map shown in Figure 15, in which the red boxes represent parts of the city which do not have public transport or are serviced with only one public line. Based on the current situation and the analysis of the coverage of the city with public city transport lines (see Figure 15), as well as on the basis of all existing data, two new lines will be added that are proposed for introduction. Their introduction as separate from the current existing lines in public urban transport, in order to gain in the increase of network lines, is shown in Figure 16.

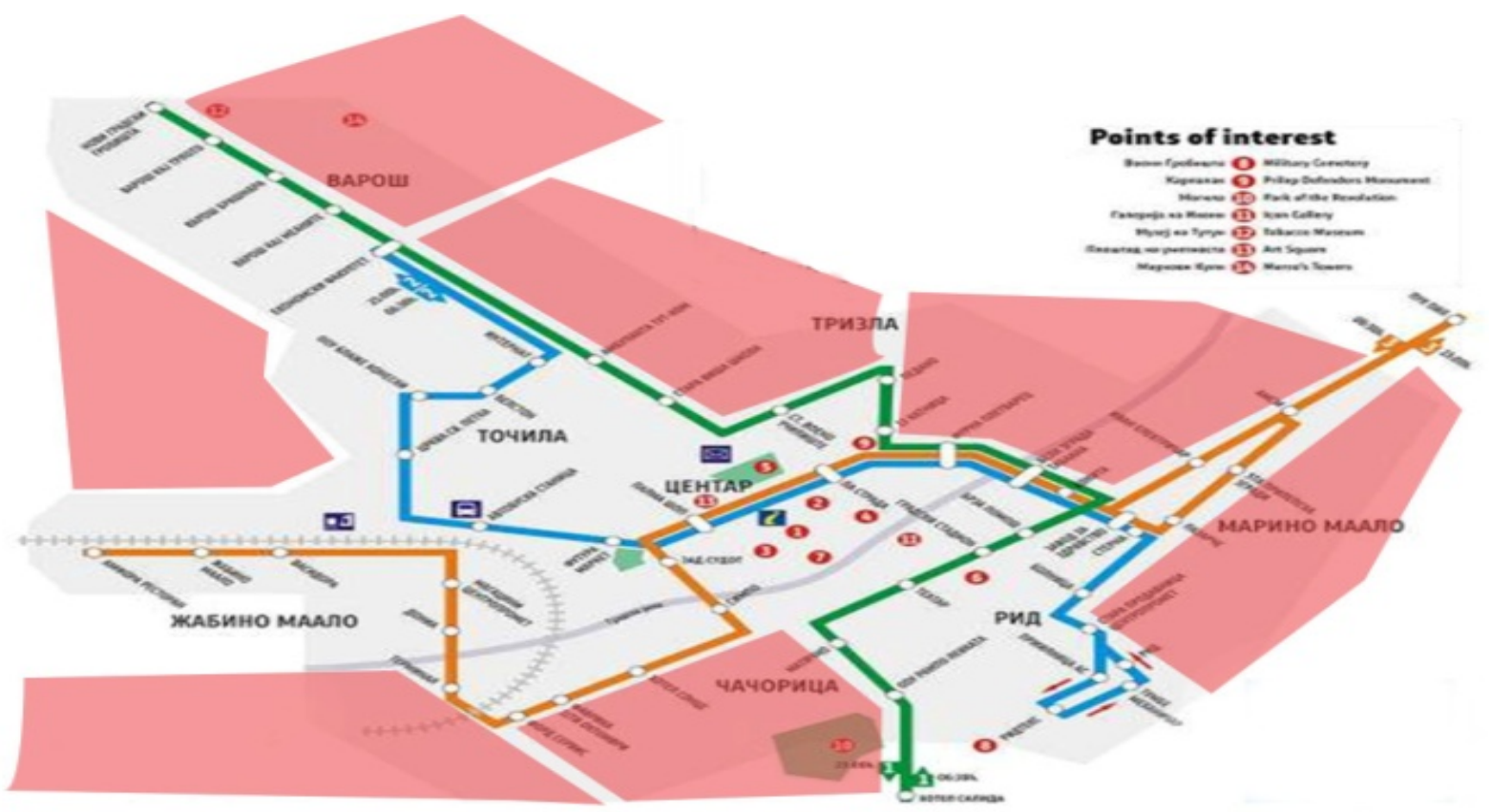

Figure 15. Parts of the city without a public transport service or only one-line service.

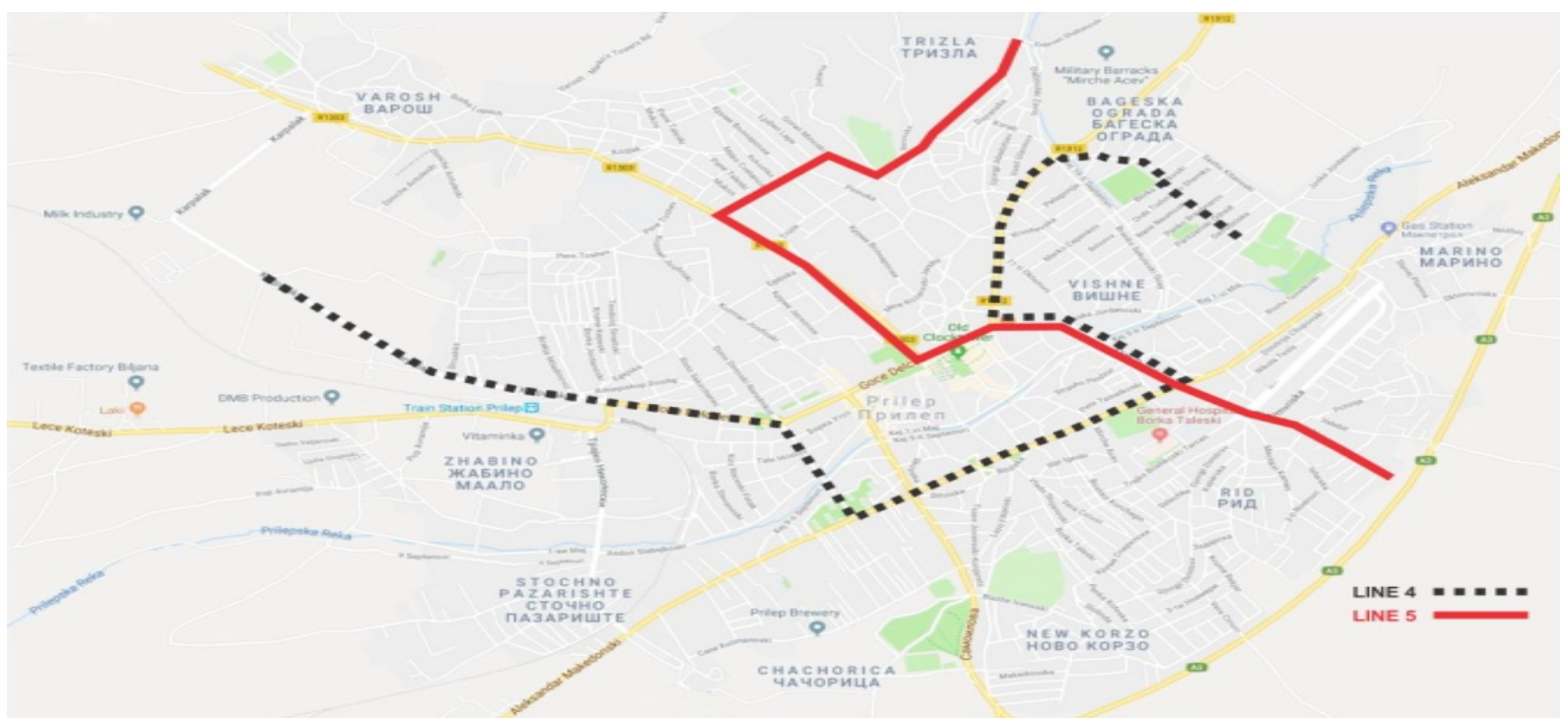

Figure 16. Two new lines proposed in the public transport in Prilep. 
It should be noted that in the projection of the new trajectories, besides the results of the survey, the characteristics of the streets of the city were taken into consideration, too, such as:

(1) A narrow profile and a small width of inclines, insufficient space for buses to travel with other vehicles, even in situations where small vans and buses are used;

(2) Large longitudinal inclines that make it impossible for buses to have normal movement, especially during bad weather (ice, snow, etc.);

(3) Small width of the flooring or lack of sidewalks, absence of a larger free space between the streets and buildings on both sides, in case of public transport, the safe movement of pedestrians is threatened;

(4) The small width of the sidewalks or the complete absence of sidewalks limits the location of bus stops;

(5) The small radius of some intersections or a curved street with a large longitudinal slope, unacceptable for normal maneuvering of freight vehicles in public transport (Krstanoski, 2017).

Because of this in certain parts of the trajectories, the proposed diametric lines have the shape of circular lines.

These restrictions contribute to changing the current coverage of public transport in Prilep (given on map shown in Figure 16), changing as well as the first design of trajectories of the newly proposed lines. The aforementioned restrictions were the main factors in defining the final design of the lines in the public city transport in Prilep. Regarding the proposed solutions for expanding public transport (see map of Figure 16), the two newly proposed lines are: Line 4 with a dashed black line will move according to the following timetable: It will depart from the Markovi Kuli basin - a type of settlement - barracks - a circular flow Monument Karpalak - a circular flow Solidness - an old theater - a man from Pimovich - Tinex to grain Prilep and back. Line 4 with a dashed black line is planned to serve the public city transport of zones: 1, 2, 3, 4, 5, 6, 7, 8, and 9 . Line 5 is red line and will move based on the following timetable: It will depart from the street Trizla at Pemba - Primary School Dobre Jovanoski - Bakery Alex of Belgrade - on the street Partizanska - in front of Tobacco Combine - Center - Lavender pizzeria - roundabout Solidness - settlement Kuzman (above Primary School Goce Delchev) and back. Line 5 is designed to serve the zones: 1, 2, 3, 4, 9, 11, 12, and 13. These newly proposed lines will provide connectivity between the central area of the city and the suburban areas that have not been sufficiently served by public urban transport so far.

Such defined lines of public urban transport and the expansion of the public traffic network should ensure the fulfillment of two basic functions: the collection and distribution of passengers and their transportation (in time and frequency).

\section{Technical Aspects of the Projection Process}

The newly proposed two lines need small constructive changes, because they will use the current road infrastructure. In certain places, in order to provide a semi-circular turn of public city transport for vehicles at the terminal terminals, constructive changes are needed (see Figure 17).

In order to ensure the smooth movement of trucks for the public in the given streets where the problem with the necessary parking space should be solved and to solve this problem, the best decision is that in certain streets parking should be completely banned in the city of Prilep. Figure 18 shows the former main bus station located in the center of the city just to the ground floor garage. Today, this space has been bought by the private company Marfil and the bus company Pelagonija. 


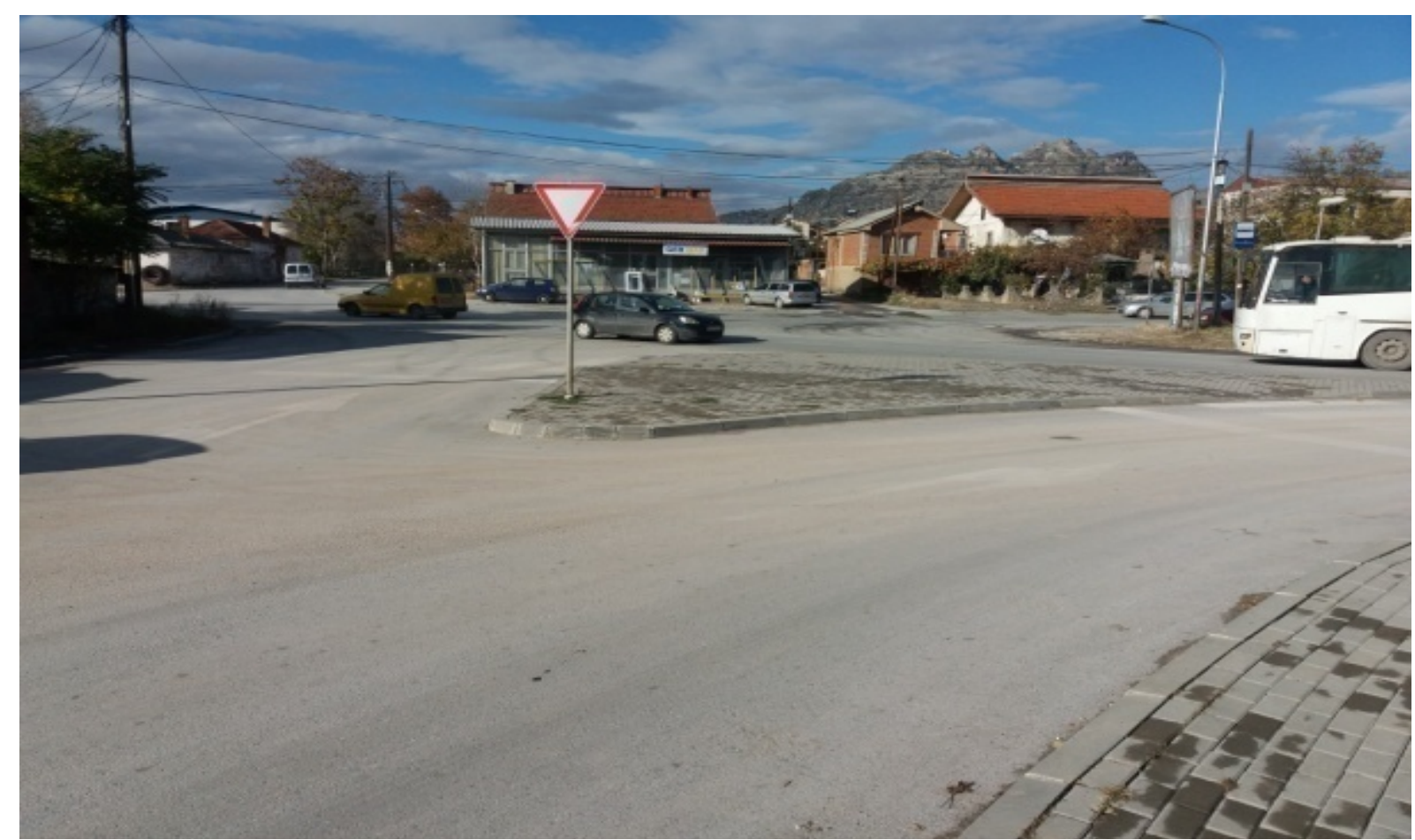

Figure 17. Terminal for which a constructive change is needed on the existing central island to ensure a circular flow. Source: By Prof. Dr. Cane Koteski on December 24, 2017.

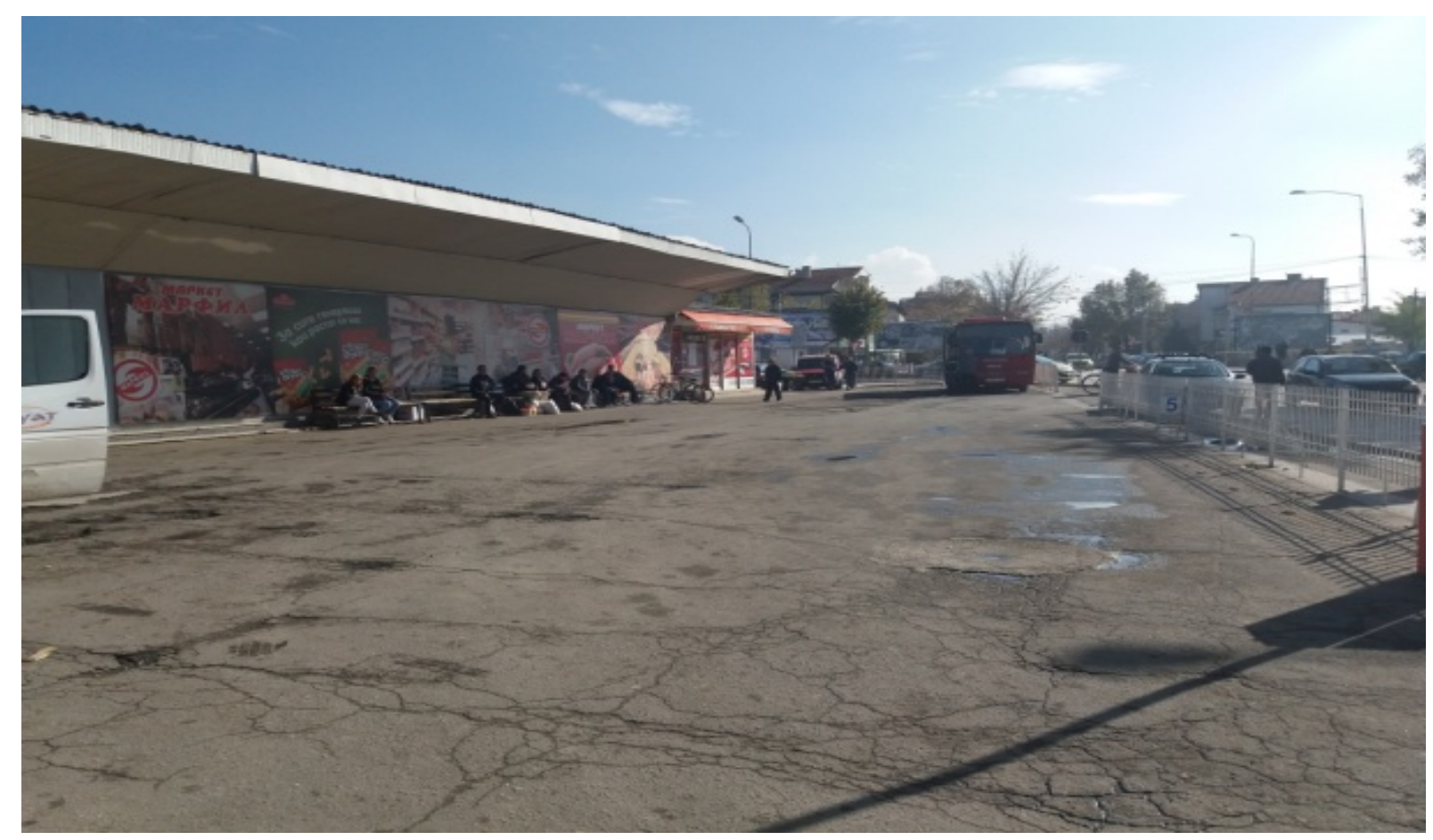

Figure 18. Former bus stop included in new trajectories. Source: By Prof. Dr. Cane Koteski on December 24, 2017. 
Streets in Figures 19 and 20 are located just behind the old bus station, in the immediate vicinity of the multi-storey garage in the city center.

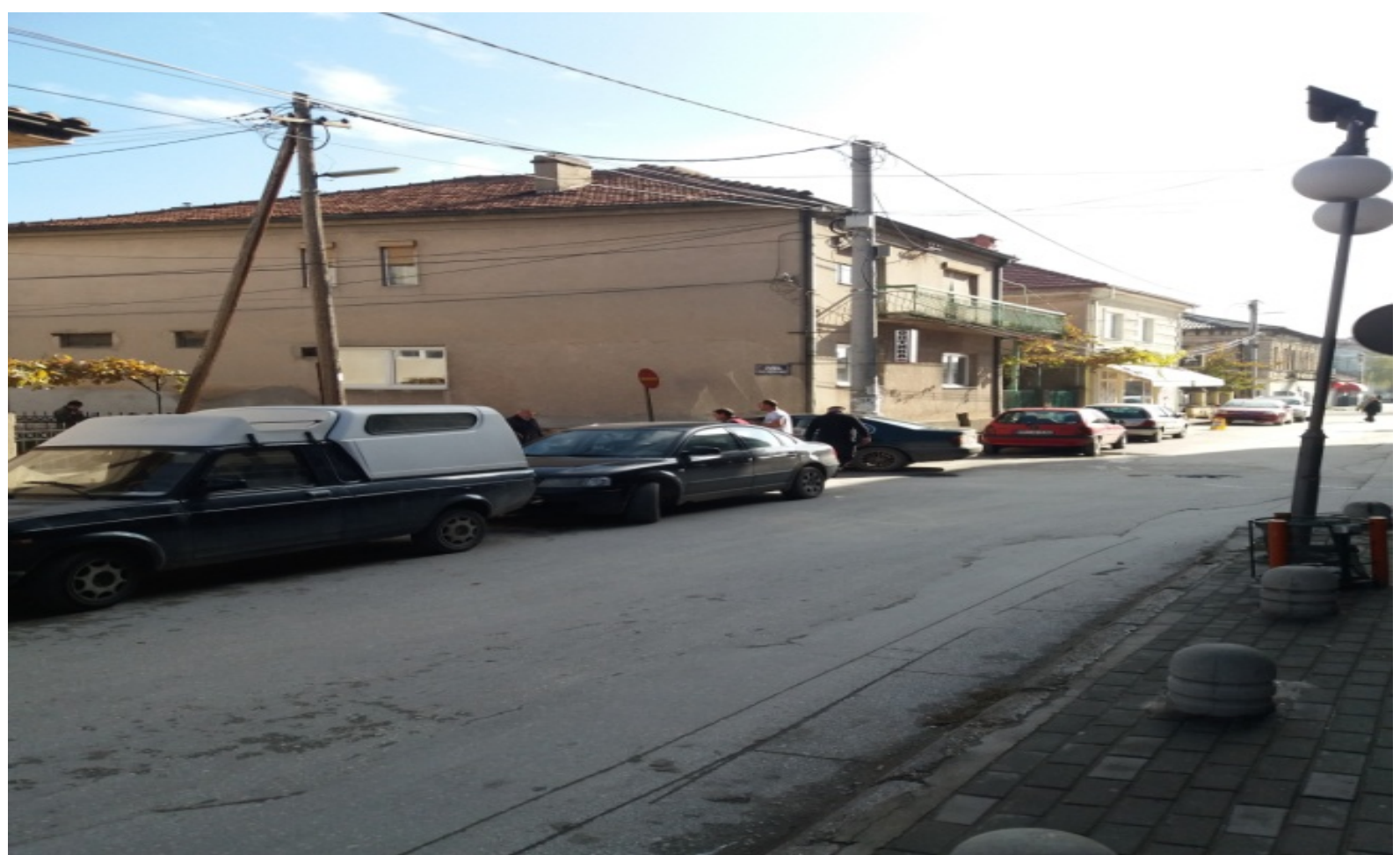

Figure 19. Parked vehicles and unsafe movement of pedestrians. Source: By Prof. Dr. Cane Koteski on December 24, 2017.

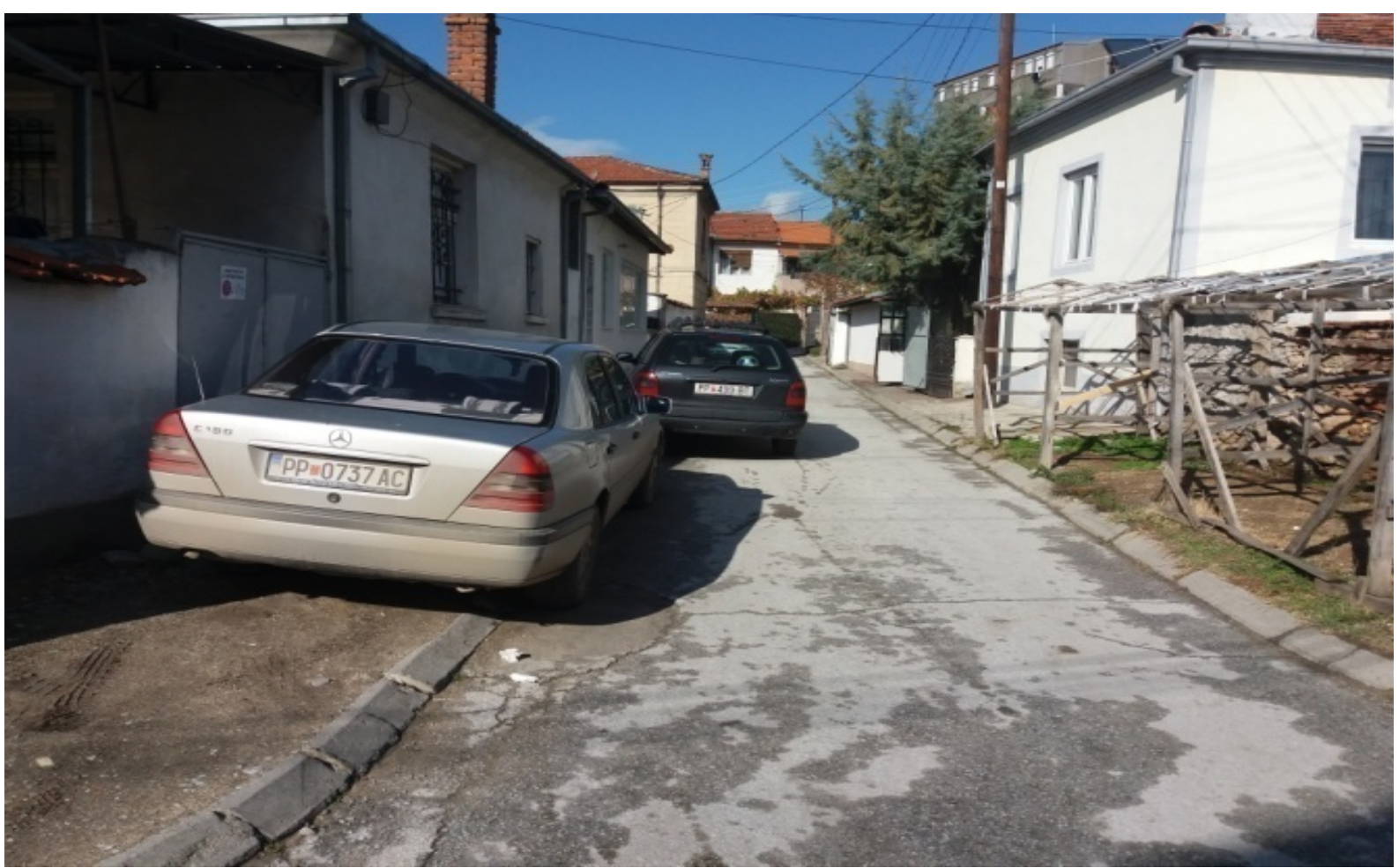

Figure 20. Obstacles, the right turns around for parked vehicles on the street. Source: By Prof. Dr. Cane Koteski on December 24, 2017. 
Trajectories of new lines with small changes can easily be adapted to changes in the flow of city traffic mode from two-way to one-way. Due to the narrow streets through which the new lines of public transport pass, we suggest using smaller public transport vehicles, for example, minibuses. This should be a standard requirement if the road infrastructure does not allow the free movement of standard large buses. The ultimate organization of the public city transport with all its elements of service such as time interval, vehicle frequency, number of vehicles on each line depends on the results of the analysis of the assessment of tourist needs, the demand for travel, and the availability of public urban transport in the places where such service is offered (Atanasova \& Angelevska, 2011).

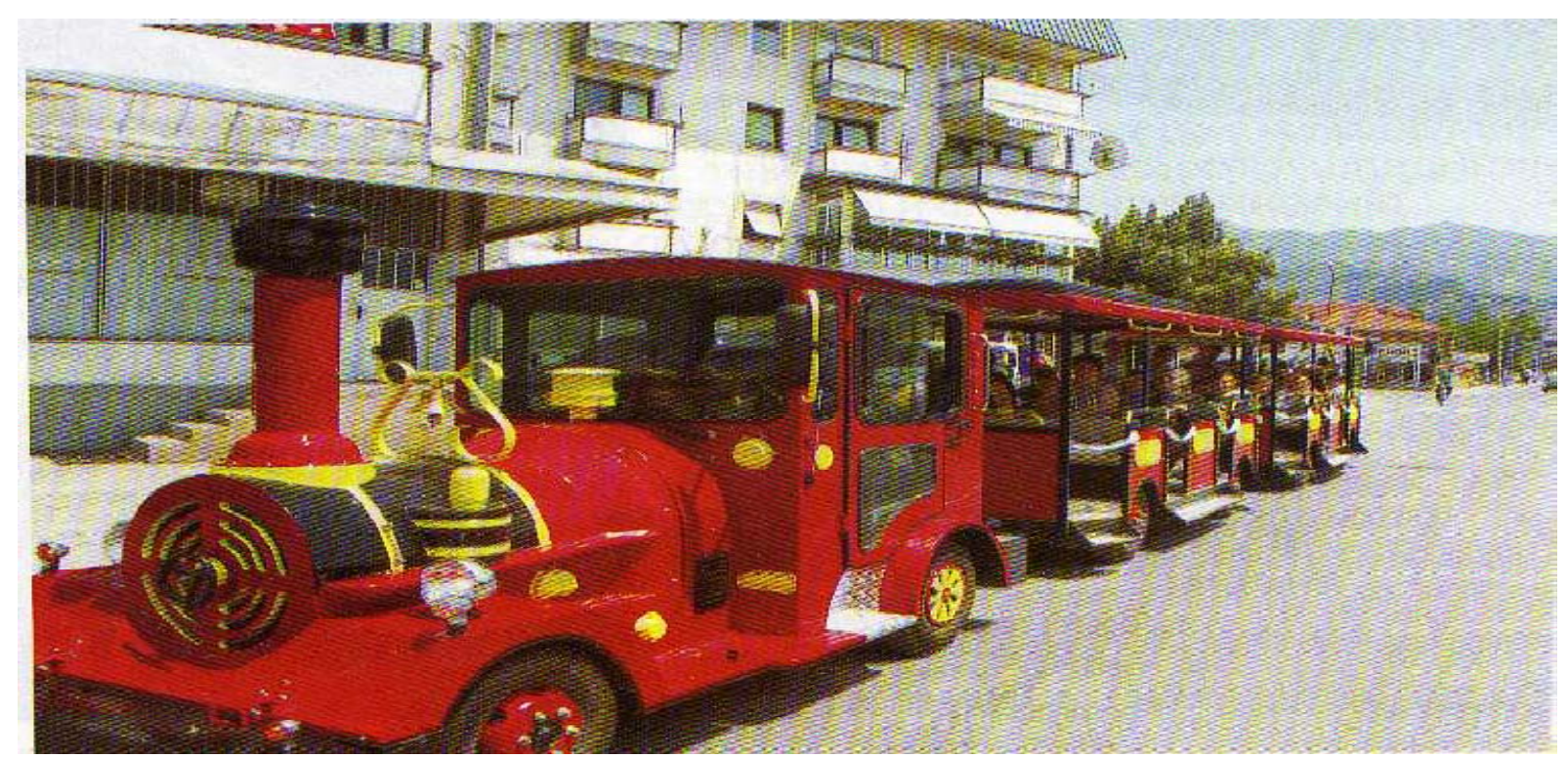

Figure 21. Panoramic train with which tourists visit all cultural and historical monuments in the city of Prilep.

Source: By Prof. Dr. Cane Koteski on January 7, 2017.

Figure 21 shows the tourist train used from May to October; the tourist train starts from the city center from the Goce Delchev Boulevard in front of the advertisements. The tourist train, when filled with passengers, makes panoramic views of the city.

In 2016, Prilep was visited by a total of 6,205 tourists, of whom 3,670 are foreign tourists and 2,535 are domestic tourists. By country, most of the tourists were from: Serbia (481), Ukraine (338), Bulgaria (274), Italy (268), Germany (262), and Greece (233) (Local Self-Government, Department for Tourism of the City of Prilep-Annual Report). In Prilep, there are excellent conditions for the development of several branches of tourism such as extreme sports climbing on rocks, motorcycle and jeep races, paragliding, cycling and cultural and historical tourism and museum tourism (Koteski, 2017c).

\section{Acquisition of Experiences With the Development of City Transport}

If the result is with the introduction of new lines to increase the number of public transport journeys and reduce travel from private cars, the idea of conducting such a scientific research was to introduce modern solutions in order to obtain a better quality of public urban transport in the city of Prilep in the Republic of Macedonia. All civil societies as well as users of public urban transport can be manifested in the following forms (Atanasova \& Angelevska, 2011): 
(1) Achieving a sustainable distribution of modal journeys;

(2) Reduction of traffic congestion in the central part of the city;

(3) Better communication and connection of the peripheral zones and the central area of city;

(4) Accessibility of the service to a greater number of users, a small need for capital investments, intended for increasing the capacity of the streets of the city of Prilep, and to be built beside the two multi-storey garages, another new multi-storey garage and new parking spaces;

(5) Environmental protection, which will refer to lower noise, the level of emissions, especially if the number of private passenger cars is reduced in the streets of the city of Prilep, use of minibuses and the use of cleaner fuels and electric vehicles for public urban transport;

(6) The possibility for urban planners to plan more space that would be intended for non-motorized traffic and parking places, thus creating the opportunity to design a more pleasant environment, where green areas, pedestrian paths, bicycle paths, and other non-motorized content will dominate (Koteski, 2017c).

The quality of information and the implementation of their urban public transport lines will oblige the public enterprise to (Tyrinopoulos \& Aifadopoulou, 2008):

(1) Take measures to improve the services;

(2) Monitor the progress of the quality of its services in the coming period;

(3) Evaluate the efficiency of the new services;

(4) Better understand of the needs and priorities of the passengers;

(5) Perform a client-oriented process of planning public services urban transport and the internal operation of the organization;

(6) Establish successful communication and cooperation among all involved parties in the local transportation system (operators, subsidiaries, ministries, municipalities, etc.);

(7) Provide support to decision-making processes with an important character (Krstanoski, 2017).

\section{Conclusion}

The main goal of all participants involved in the work of public transport is to create a well-organized transport system, where citizens will be able to find a good level of mobility and meet their needs for efficient movement under safe and comfortable conditions. The whole process carries with it very important high-quality features of public urban transport, such as efficiency, security, availability, time information, etc. Because of this scientific paper, the paper mainly studies urban transport and its application in tourism. The municipality provided licensed tourist guides that welcome tourists arriving in the city of Prilep. The municipality within the city public transport company bought a tourist train that operates seasonally from April to October. The city transport for tourism is of paramount importance as it contributes to tourism in the transport of larger and smaller tourist groups, both through the city and to nearby destinations of the city of Prilep in the Republic of Macedonia.

The quality of public urban transport stems from the ability of the respective companies to manage and further develop their services (Tyrinopoulos \& Aifadopoulou, 2008). Especially in public transport, quality of services (or the most important issue), improving the level of quality can attract more users. To increase the use of public urban transport by reducing the use of private cars can help to reduce many problems, such as crowds in traffic, environmental pollution, consumption of fossil fuels as energy (Eboli \& Mazzulla, 2008). When there is no absence of the policy for the development of public urban transport, and in case when the role and 
importance of the public city transport for the quality of urban life are underestimated, today in Prilep there is an intermediate good condition and medium public transport services. Because of all the previously mentioned public transport in Prilep, it is obvious that the quality of the service is at the intermediate level. Regularity and accuracy are satisfactory; travel time is good; carriers have problems with vehicle aging and maintenance of routes; passengers have enough information, as well as the condition of bus stops in the central part of the city is good, while on the periphery the situation with bus stops, the comfort in public transport vehicles is at a satisfactory level. The given solution for improving the public transport is the result of the function, the role and the importance that the public urban transport has a sustainable urban transport. The introduction of the two new lines will provide an improvement in the level of services; public transport will be enriched and extended to the peripheral parts of the city of Prilep. Thus, these two new lines will provide greater coverage of public transport services, especially for those parts of the city that have minimal or insufficient service. The new lines will provide increased availability of public transport for a larger number of users. Thus, in addition to private cars, citizens will have at their disposal one more sustainable opportunity to use city trips. The done researches for improving the quality of public transport in the city and their impact on the satisfaction indicate that the experience of satisfaction with the use of public transport services is under the influence of quality improvement only to some extent. There may be several reasons for this, sometimes quality improvement can be realized over long periods of time during which some service disruptions occur:

(1) Critical negative incidents are considered situations intended for the performance of a service that does not meet expectations;

(2) Management and planning with some departments of the public enterprise can have difficulties in cooperation and communication.

Traffic planners and decision makers always fail at the stage of introducing new lines in public city transport. They should think about mass informing of the population according to quality programs. It is a long way to increase the quality of public transport in Prilep and improve its performance as a whole. With the introduction of new lines, the local government should promote and provide realistic conditions for massive use of public urban transport. They should provide conditions for defining the organizational and financial framework in public urban transport. The existing government should create a climate for overcoming all the problems that have arisen, the improvement can be achieved with the public transport service, and the citizens of Prilep can finally feel the benefits of high-quality public transport.

\section{References}

Atanasova, V., \& Angelevska, B. (2011). Preliminary solutions for the public transport in the Bitola town. Pilot Project 5. Traffic study for the Bitola town.

Eboli, L., \& Mazzulla, G. (2007). Service quality attributes affecting customer satisfaction for bus transit. Journal of Public Transportation, 10(3), 21-34.

Eboli, L., \& Mazzulla, G. (2008). A stated preference experiment for measuring service quality in public transport. Transportation Planning and Technology, 31(5), 509-523.

Fellesson, M., \& Friman, M. (2008). Perceived satisfaction with public transport service in nine European cities. Journal of the Transportation Research Forum, 47(3), 93-103.

Koteski, C. (2017a). Traffic in tourism, bus traffic. Faculty of Tourism and Business Logistics-Gevgelija, Goce Delcev University-Stip, Macedonia.

Koteski, C. (2017b). Traffic in tourism, bus fleets. Faculty of Tourism and Business Logistics-Gevgelija, Goce Delcev University-Stip, Macedonia. 
Koteski, C. (2017c). Traffic in tourism, not motorized transport and tourism, study: Bicycle tourism, bicycle tourism in Macedonia. Faculty of Tourism and Business Logistics - Gevgelija, Goce Delcev University - Stip, Macedonia.

Krstanoski, N. (2003). Public transport planning. University “St. Kliment Ohridski”, Faculty of Technical Sciences, Bitola, Macedonia.

Krstanoski, N. (2006). Public transport. University “St. Kliment Ohridski”, Faculty of Technical Sciences, Bitola, Macedonia.

Krstanoski, N. (2017). Advancement of public transport service in Bitola. TEM Journal, 6(1), 53-63.

Krstanoski, N., \& Atanasova, V. (2008). A strategy for development of public transport in the city of Skopje 2008-2018. Faculty of Technical Sciences, Bitola, Macedonia.

Local Self-Government, Department for Tourism of the City of Prilep—annual report.

Porta, S., \& Scheurer, J. (2006). Centrality and connectivity in public transport networks and their significance for transport sustainability in cities. Paper presented at The World Planning Schools Congress. Global Planning Association Education Network, July 13-16, Mexico.

Roy, W., \& Billon, Y. A. (2007). Ownership, contractual practices and technical efficiency: The case of urban public transport in France. Journal of Transport Economics and Policy, 41(2), 257-282.

Sumaedi, S., Bakti, M. Y. G., \& Yarmen, M. (2012). The empirical study of public transport passengers’ behavioral intentions: The roles of service quality, perceived sacrifice, perceived value, and satisfaction (case study: Paratransit passengers in Jacarta, Indonesia). International Journal for Traffic and Transport Engineering, 2(1), 83-97.

TRL. (2004). The demand for public transport: A practical guide. TRL Report 593.

Tyrinopoulos, Y., \& Aifadopoulou, G. (2008). A complete methodology for the quality control of passenger services in the public transport business. European Transport/Transporti Europei, 38, 1-16. 